Hal.

\title{
PENGARUH GAYA BERENANG (GAYA BEBAS DAN GAYA DADA) TERHADAP PERUBAHAN VOLUME OKSIGEN MAKSIMUM
}

\author{
Dennison*, Endang Sriwahyuni**, Viera Wardhani*** \\ * Mahasiswa Fakultas Kedokteran Unibraw \\ ${ }^{* *}$ Laboratorium Fisiologi Fakultas Kedokteran Unibraw \\ *** Laboratorium IKM-KP Fakultas Kedokteran Unibraw
}

\begin{abstract}
Swimming is frequently used to improve the individual physical endurance. Most of the studies have proved that swimming can improve the maximum oxygen volume effectively, but none of them compare the differences in the swimming styles. The study was aimed to analyse the differences of swimming styles in improving maximum oxygen volume, so it can be used as basis for physical training scheme. A pretest-posttest experimental design was conducted in two sample group (front crawl stroke group and breast stroke group) consists of six people in each group. The samples were selected based on questionaire to control the confounding variables, ie: sex, age, height, weight, training habit and health status (anemia, heart disease and respiratory distress). The training method were carried out in 12 session in 4 weeks ( 3 session per week) by increasing the swimming distance gradually. Each session arrangement was consists of warming up - training in short sets with rests - relaxation. The maximum oxygen volume was measured using Cooper method and the result was analyzed using independent sample t-test with SPSS 11. The result shows that there is a significant difference in maximum oxygen volume improvement ( $t=-4.718, C l 95 \%=l o w e r:-5.014$; upper: $-1.722, p=0.002)$ in which the result in breast stroke group has a higher improvement (mean: 6.313, sd: 1.378) compared to front crawl stroke group (mean: 3.203, sd: 1.941). This result may due to the glide position in breast stroke, the variation of measuring maximum oxygen volume and physiological variation of the swimmers
\end{abstract}

Key words: Swimming Style, Maximum Oxygen Volume

\section{ABSTRAK}

Latihan berenang banyak menjadi pilihan sebagai olahraga ketahanan yang di-tujukan untuk meningkatkan dan memelihara ketahanan fisik. Berbagai studi telah mengkaji efektifitas berenang dalam meningkatkan volume oksigen maksimum sebagai salah satu indikator ketahanan fisik. Namun belum ada studi yang secara spesifik mengkaji perbedaan gaya dalam latihan berenang terhadap peningkatan volume oksigen maksimum. Studi ini ditujukan untuk mengkaji pengaruh perbedaan gaya dalam latihan berenang terhadap peningkatan volume oksigen maksimum, sehingga dapat menjadi dasar dalam pilihan olah raga berenang. Penelitian dilakukan dengan pretest-postest experimental design pada kelompok latihan gaya bebas dan gaya dada dengan masingmasing kelompok terdiri dari enam orang coba. Pemilihan sampel orang coba dilakukan dengan seleksi menggunakan kuesioner untuk mengendalikan variabel pengganggu, yaitu jenis kelamin, usia, berat badan, tinggi badan, kebiasaan berolahraga dan gangguan kesehatan diantaranya anemia, penyakit jantung dan gangguan pernafasan. Latihan berenang dilakukan dalam 12 sesi latihan selama 4 minggu (3 sesi seminggu) dengan peningkatan jarak tempuh secara bertahap. Dalam setiap sesi latihan dilakukan dengan metode pemanasan - latihan dalam set pendek yang diselingi istirahat - relaksasi. Pengukuran volume oksigen maksimum dilakukan dengan metode Cooper, sedangkan analisis data dilakukan dengan uji independent sample t-test menggunakan SPSS 11. Hasil penelitian ini menunjukkan adanya perbedaan rata-rata peningkatan volume oksigen maksimum setelah latihan $(t=-4,718, \mathrm{Cl}$ 95\% = lower: $-5,014$; upper: $-1,722$ dan $p=0,002)$ dengan peningkatan lebih tinggi ditemukan pada kelompok gaya dada (mean: 6,313 , sd: 1,378) dibanding kelompok gaya bebas (mean: 3,203, sd: 1,941). Perbedaan tersebut dapat disebabkan oleh adanya fase meluncur pada gaya dada, variasi dari pengukuran volume oksigen maksimum dan variasi fisiologis orang coba.

Kata kunci: Gaya Berenang, Volume Oksigen Maksimum

\section{PENDAHULUAN}

Dalam olahraga, salah satu kunci untuk meraih kemenangan terletak pada ketahanan tubuh seorang atlet. Penelitian menunjukkan bahwa orang yang memiliki kapasitas konsumsi oksigen yang besar umumnya tampil lebih baik dalam pertandingan olahraga yang perlu ketahanan tubuh (1).

Volume oksigen maksimum $\left(\mathrm{VO}_{2}\right.$ maksimum) secara fungsional menunjukkan jumlah maksimum oksigen yang dapat diambil dari darah sirkulasi dan digunakan oleh jaringan-jaringan yang bekerja selama periode tertentu (2). $\mathrm{VO}_{2}$ maks ini dapat ditingkatkan dengan latihan ketahanan (3). Karena berenang merupakan salah satu dari olahraga ketahanan, maka latihan berenang akan dapat meningkatkan $\mathrm{VO}_{2}$ maksimum.

Berenang dapat dilakukan dalam beberapa gaya yang berbeda. Dua gaya berenang yang umum digunakan adalah gaya bebas dan gaya dada. Gaya bebas merupakan gaya yang termudah dan paling adekuat untuk melatih sistim sirkulasi dan respirasi serta menstimulasi volume konsumsi oksigen maksimum 
Hal.

(4). Sedangkan gerakan dalam gaya dada dianggap sebagai gerakan istirahat. Gaya bebas merupakan gaya dengan gerakan yang ritmis pada kaki dengan kayuhan yang bergantian pada lengan sedangkan gaya dada memiliki gerakan simetris pada dua sisi tubuh, dengan pergantian gerak antara kaki dan lengan disertai fase meluncur (5).

Berbasis pada fakta teoritis perbedaan gaya dada dan gaya bebas, menarik untuk dikaji apakah terdapat pengaruh perbedaan gaya dalam program latihan berenang terhadap peningkatan $\mathrm{VO}_{2}$ maksimum. Tujuan dari penelitian ini adalah untuk mengetahui pengaruh perbedaan gaya berenang, antara gaya bebas dan gaya dada, terhadap perubahan $\mathrm{VO}_{2}$ maksimum. Diharapkan hasil dari penelitian ini dapat menjadi dasar dalam mengembangkan program latihan olahraga ketahanan bagi atlet serta masyarakat umum.

\section{MATERI DAN METODE}

Penelitian dilakukan dengan rancangan pretest-posttest experimental design dengan dua kelompok perlakuan yaitu gaya bebas dan gaya dada, dan pengukuran volume oksigen maksimum sebagai outcome. Dua belas orang subyek dipilih dengan kriteria: laki-laki yang berumur 21-25 tahun dengan berat badan $60-70 \mathrm{~kg}$ dan tinggi badan $165-175 \mathrm{~cm}$; bukan perenang terlatih dan frekuensi olahraga rutin maksimal 2 kali seminggu; tidak mengalami gangguan kesehatan berupa sakit jantung, gangguan pernafasan berat, anemia berat atau sering pingsan, atau cedera yang menyebabkan gangguan gerak menetap. Subyek penelitian diambil dari mahasiswa laki-laki yang tinggal di Malang, diseleksi dengan kuesioner. Persetujuan keikutsertaan dilakukan dengan penandatanganan lembar persetujuan yang tersedia.

Ke duabelas subyek secara random ditetapkan sebagai kelompok perlakuan I (gaya bebas dan kelompok perlakuan II (gaya dada). Perlakuan latihan berenang dan pengukuran outcome $\left(\mathrm{VO}_{2}\right.$ maksimum) diberikan dengan prosedur sebagai berikut:

1. Penelitian dimulai dengan pretest berupa pengukuran $\mathrm{VO}_{2}$ maksimum masing-masing orang coba. Pengukuran berupa lari dengan cara Cooper selama 12 menit. Jeda waktu untuk istirahat sebelum mulai latihan berenang selama maksimal 2-3 hari. $\mathrm{VO}_{2}$ maksimum sebelum latihan dimulai tidak akan mengalami perubahan yang berarti selama periode istirahat tersebut karena peningkatan $\mathrm{VO}_{2}$ maksimum hanya bisa diperoleh dari akumulasi latihan.

Besar $\mathrm{VO}_{2}$ maksimum ditentukan dengan perhitungan menurut cara Cooper :

$\mathrm{VO}_{2}=\{0,0225 \mathrm{X}$ jarak lari yang ditempuh dalam 12 menit (meter) $\}-11,3$

$\mathrm{VO}_{2}$ maksimum menggunakan satuan $\mathrm{ml} / \mathrm{kg} /$ menit (6).

2. Metode latihan berenang dilakukan sebagai berikut:

- Pemanasan selama 10 menit. Berupa berenang dengan kecepatan 60\%-70\% kecepatan maksimum menggunakan gaya yang telah ditentukan dalam kelompok masing-masing (3).

- Latihan :
- Kecepatan yang digunakan sebesar $80 \%-85 \%$ kecepatan maksimum.

- Waktu istirahat sebesar setengah dari waktu latihan dalam tiap set.

- Set yang telah ditentukan diulang sampai mencapai jarak tempuh total pada hari itu.

Pada pertemuan pertama, jarak yang harus ditempuh 300 meter (3).

- Relaksasi selama 10 menit. Berupa berenang dengan kecepatan 60\%-70\% kecepatan maksimum menggunakan gaya yang telah ditentukan dalam kelompok masing-masing (3).

Latihan ini dilakukan 3 kali seminggu, selama satu bulan atau 12 kali pertemuan. Pada latihan inti dilakukan penambahan jarak tempuh secara bertahap, yaitu sebesar 100 meter tiap 3 kali pertemuan.

3. Post test dilakukan maksimal 2 hari setelah latihan yang terakhir. Karena setelah 2 hari akan mulai terjadi penurunan dari $\mathrm{VO}_{2}$ maksimum orang coba (3).

4. Dicari selisih dari hasil pretest dan posttest tiap-tiap orang coba. Selanjutnya dari tiap kelompok dicari rata-rata selisih $\mathrm{VO}_{2}$ maksimum.

5. Rata-rata peningkatan $\mathrm{VO}_{2}$ maksimum dari kedua kelompok perlakuan diuji dengan uji beda rata-rata, yaitu $t$ test.

Uji statistika untuk membandingkan rata-rata $\mathrm{VO}_{2}$ maksimum dari dua kelompok menggunakan uji beda rata-rata dengan independent $t$ test. Penghitungan dan analisa data menggunakan program SPSS.

\section{HASIL PENELITIAN}

Volume oksigen maksimum diukur secara tidak langsung menggunakan metode lari cara Cooper. Tabel 3.1 menyajikan hasil pengukuran volume oksigen maksimum yang merupakan konversi dari hasil pengukuran jarak tempuh lari dengan menggunakan rumus Cooper.

Hasil tersebut menunjukkan adanya peningkatan $\mathrm{VO}_{2}$ maksimum dari hasil pretest ke posttest. Peningkatan terjadi pada tiap orang coba, baik dari kelompok gaya bebas maupun kelompok gaya dada. Bila dibandingkan antara kedua kelompok terdapat perbedaan dari rata-rata $\mathrm{VO}_{2}$ maksimum, hasil rata-rata yang lebih besar ada pada kelompok gaya dada.

Dari hasil penghitungan dengan $t$-test diperoleh $\mathrm{t}$ hitung sebesar $-4,718$. Dengan df 8 , tingkat kepercayaan $95 \%$, two tailed, didapatkan $t$ tabel sebesar 2,306. Berarti t hitung berada di luar area penerimaan Ho. Jadi Ho ditolak dan Ha diterima. Dengan demikian dapat disimpulkan dari analisa t-test tersebut bahwa: terdapat perbedaan dari peningkatan rata-rata volume oksigen maksimum pada kelompok dengan latihan gaya bebas dan gaya dada. 
Hal.

Tabel 3.1 Hasil Pengukuran Volume Oksigen Maksimum dari Pretest dan Posttest

\begin{tabular}{|l|c|c|c|c|}
\hline Kelompok & Orang Coba & VO2 Max Pretest & VO2 Max Posttest & Selisih VO2 Max \\
\hline Gaya & 1 & 37.345 & 40.787 & 3.442 \\
Bebas & 2 & 22.421 & 24.423 & 2.002 \\
& 3 & 26.95 & 33.471 & 6.521 \\
& 4 & 20.88 & 25.022 & 4.142 \\
& 5 & 35.995 & 37.633 & 1.638 \\
& 6 & 31.135 & 32.607 & 1.472 \\
\hline & & & Mean & 3.203 \\
& & & Standar Deviasi & 1.941 \\
\hline \multirow{3}{*}{ Gaya } & 1 & 36.081 & 43.33 & \\
Dada & 2 & 37.57 & 41.98 & 7.249 \\
& 3 & 32.625 & 38.65 & 4.41 \\
& 4 & 31.556 & 39.897 & 6.025 \\
& 5 & 30.28 & 36.708 & 6.341 \\
& 6 & 20.583 & 26.005 & 6.428 \\
& & & Mean & 6.422 \\
\hline
\end{tabular}

\section{PEMBAHASAN}

Dari hasil analisa t-test didapatkan kesimpulan bahwa terdapat perbedaan dari peningkatan rata-rata volume oksigen maksimum pada kelompok dengan latihan gaya bebas dan gaya dada, dengan rata-rata volume oksigen maksimum dari kelompok gaya dada lebih tinggi daripada kelompok gaya bebas. Hal ini berbeda dari teori yang menyebutkan bahwa gaya bebas merupakan gaya yang paling adekuat untuk mening-katkan volume oksigen maksimum (4).

Faktor penyebab yang mungkin adalah terdapatnya perbedaan dari kedua gaya, yaitu pada fase meluncur pada gaya dada. Seperti yang disebutkan dalam tinjauan pustaka, dalam gaya dada terdapat fase meluncur, yang bisa dianggap pula sebagai fase istirahat, karena pada saat itu tubuh terdorong ke depan begitu saja tanpa perlu gerakan tambahan. Fase meluncur ini tidak terdapat dalam gaya bebas (5).

Perbedaan ini bisa dianalogikan dengan teori bahwa berenang dengan set-set pendek dengan diselingi istirahat akan lebih efektif dalam meningkatkan volume ok-sigen maksimum. Adanya istirahat di sela latihan akan memberi hasil yang lebih baik karena kelelahan diperlambat. Bila fase meluncur dalam gaya dada diasumsikan sebagai fase istirahat, maka dapat diartikan bahwa dalam gaya dada terdapat waktu istirahat ekstra, di mana dalam gaya bebas tidak didapatkan. Dilihat dari sudut pandang demikian, maka penggunaan gaya dada akan lebih memperlambat kelelahan dibandingkan gaya bebas, dan pada akhirnya akan menghasilkan peningkatan volume oksi-gen maksimum yang lebih tinggi (3).

\section{KESIMPULAN DAN SARAN}

Hasil penelitian menunjukkan bahwa perbedaan gaya berenang (gaya bebas dan gaya dada) mempunyai pengaruh dalam rata-rata peningkatan volume oksigen maksimum, dimana latihan dengan gaya dada mempunyai rata-rata peningkatan lebih tinggi dibanding latihan berenang dengan gaya bebas. Perbedaan tersebut disebabkan adanya fase meluncur dalam gaya dada yang dapat diidentikkan sebagai fase istirahat dalam satu set latihan. Adanya fase istirahat dapat memberikan peningkatan volume oksigen maksimum yang lebih tingggi dibandingkan dengan set latihan tanpa fase istirahat.

Secara keseluruhan hasil penelitian juga menunjukkan bahwa program latihan berenang baik gaya bebas maupun gaya dada dapat meningkatkan volume oksigen maksimum. Sehingga program tersebut dapat dijadikan program latihan ketahanan baik bagi atlet renang, pelatih renang, maupun perenang biasa.

Adanya perbedaan hasil penelitian ini dengan teori sebelumnya mendukung perlunya penelitian lebih lanjut dengan kontrol yang lebih ketat pada karakteristik orang coba. Hal ini perlu dilakukan supaya faktor pengganggu makin sedikit dan hasil penelitian menjadi lebih valid.

\section{DAFTAR KEPUSTAKAAN}

1. Costill, D.L., Adaptation in Skeletal Muscle During Training for Sprint and Endurance Swimming; Swimming Medicine IV (Eds.) Baltimore. University Park Press. 1978: 233-248.

2. Kimura, Y., Simulated Swimming: A Useful Tool For Evaluating the VO2 Max in Laboratory. British Journal of Sport Medicine. 1990.

3. Maglischo, E.W., Swimming Faster. Chico. Mayfield Publishing Company. 1982: 270-313.

4. Trummer, P., 2001. (http//www.swimefsl.ritanet.net/coach201.htm, diakses 22 Mei 2002)

5. Parker, J., Wiping Your Swimmers Out. Swimming Technique. 1990

Maj. Kedok. Unibraw Vol. XIX, No.2, Agustus 2003 